\title{
Present Situation of Urbanization in Nepal
}

\author{
Damodar Chapagain* \\ Teaching Assistant, M R. M Campus, Ilam, Tribhuvan University, Nepal \\ *Corresponding Author: Damodar Chapagain, Teaching Assistant, M R. M Campus, Ilam, Tribhuvan \\ University, Nepal
}

\begin{abstract}
Urbanization is the process of being urban area with some significant demographic and socio-economic development. It is the process that leads to specialization, industrialization, economic growth and concentration of population. In Nepal, criteria in defining urban area are changing over the time. However, different acts and agencies have adopted population size, and annual income and availability of infrastructure as the major criteria in defining urban area. Being least urbanized country, the process of growing urban center and population has increased from 10 urban area with 2.9 percent population in 2052/54 to 217 with 41.7 percent in 2015 AD in Nepal. The newly adopted administrative structure after the 2015, has declared 293 urban areas where 62 percent people live. Still the distribution of urban areas and population is by province and ecological zones.
\end{abstract}

Keywords: Urbanization, Urban Center, Population, Municipalities, Province, Ecological Zone

\section{INTRODUCTION}

Urbanization is the process of concentration of population in certain localities. It is the process of changing rural area to urban (Subedi, 2011) by increasing the proportion of population living in urban areas. It is mostly contributed by moving from rural areas to cities or to densely inhabited area. It is the structural change from agricultural based employment to non-agricultural, industrial pattern of employment where basic facilities area available. According to the Thompson and Lewis "urbanization refers to the process whereby an increasing country's population comes to live in cities ". Densely populated area which pursues the rapid growth of population, specialization, industrialization, infrastructure and economic development is generally known as urbanization (Chapagain, 2008). Mostly urbanization is related to diversity of people in terms of caste/ethnic and religious composition, economic growth, availability of skill and quality of human resources. UNFPA (1996) defined 'urban area as having administrative unit, population concentration, proportion of population in non-agricultural occupation and availability of infrastructural facilities'.

Nepal is the least urbanized country in the world. However, urbanization is gradually taking place even through the country is still predominantly rural character because the more than 40 percent population are under agricultural occupation and living far from use of modern technology .However, the urbanization has become the vital agenda for development of Nepal (CBS,2003). The history of Nepalese urbanization began in Nepal when 2052/054 population census provided data of 10 prominent settlement having 2.9 percent population. This figure has highly changed. By 2015 there have been 217 municipalities where 41.7 percent population of the country. Their nature of urban development vary in temporal and spatial context from 2052/054 to 2015 AD. In this paper, it has attempted to review the state of urban places, population, their changing trend and pattern in Nepal.

\section{Method AND MATERIALS}

Urbanization is the significant indicator of the socio-economic development. In Nepal, people who are living in municipalities are called urban population. Subedi (2014) argued that three basis such as 'economic structure, functional bases and contiguity of settlement' should be considered in declaring urban area. Now, one question has rose that whether the present municipal area decelerated by the government of Nepal has maintained such criteria or based on what the present 293municipalities are declared as urban center. However, this article has tried to discuss and compare of demographic aspects like population size and spatial pattern and state of geographical distribution of all 217 municipalities declared following the criteria of local self-government act-1999 of Nepal. The 
required data and information are taken from different published and unpublished secondary sources like book, published journal article, population monograph, government's website etc. The major source of data is the Central Bureau of Statistics of Nepal that publish census and other different survey's data in Nepal. In addition, the various ministries such as Ministry of Local Development and Federal Affairs also publish data and reports on demography, urban areas are also considered.

\section{RESULT AND DISCUSSION}

\subsection{Disparity in 'Urban' Concept and Definition}

The term 'urban' is a region with large built -up area. The definitions of urban vary by every country. For example in Philippines, national center having 500 persons per square meter, six commercial, manufacturing, at least three town halls, park, administrative building etc. are considered as urban place.

In Nepal, definition of urban area has been continuously changing over the time. There is no uniformity in defining urban area which has brought the difficulties in reviewing the state of urbanization in Nepal. Fifth population census, was the first scientific census conducted in 2052/54 BS recognized ten settlement named 'prominent settlement' with the basic of criteria of population size to 5000only.The 1961 census was internationally accepted scientific census which for the first time defined an urban as " an area with the population of 5000" and above and having other facilities like, high school, college, judicial and administrative units , market ,communication facilities, mills, factories . In such a way, the definition of urban has changed in 1996 census. Chapagain (2008) pointed out the changing definition of urban that shown below table 1 .

Table1. Changing criteria of urbanization in Nepal

\begin{tabular}{|c|c|c|}
\hline Years & Criteria & Remarks \\
\hline $1952 / 54$ & - $\quad$ population over 5000 & Un cleared criteria 'Prominent' settlement ' \\
\hline 1961: Census & $\begin{array}{l}\text { - Population over } 500 \\
\text { - } \quad \text { urban environment }\end{array}$ & 'Sahar' \\
\hline $\begin{array}{l}\text { 1962: Nagar } \\
\text { Panchayat } \\
\text { Act }\end{array}$ & $\begin{array}{ll}\text { - } & \text { Population at least } 10,000 \\
\text { - } & \text { Local urban administrative unit } \\
\text { - } & \text { Local government unit } \\
\end{array}$ & 'Nagarpalika' \\
\hline 1976 & Population size at least 9000 & 'Nagar panchayat' \\
\hline $\begin{array}{l}\text { 1992: } \\
\text { Municipal act }\end{array}$ & Population size at least 9000 & 'Nagarpalika' \\
\hline $\begin{array}{l}1992 \\
\text { Municipality } \\
\text { act }\end{array}$ & $\begin{array}{ll}\text { - } & \text { Population size } 20000 \\
\text { - } & \text { Basic urban infrastructures } \\
\text { - } & \text { Minimum one million annual revenue } \\
\text { - } & \text { semi- urban environment } \\
\end{array}$ & 'Nagarpalika' \\
\hline \multirow[t]{3}{*}{$\begin{array}{l}\text { 1999: } \\
\text { Local Self } \\
\text { Governance } \\
\text { Act }\end{array}$} & $\begin{array}{l}\text { Redefined the Urban Area } \\
\text { - } \quad \text { Population size } 300000 \\
\text { - } 400 \text { million annual revenue } \\
\text { - } \quad \text { Urban environment } \\
\text { - } \quad \text { High education facilities }\end{array}$ & $\begin{array}{l}\text { 'Mahanagarpalika' } \\
\text { ( Metropolitan City) }\end{array}$ \\
\hline & $\begin{array}{l}\text { - } \text { Population Size } 100000 \\
\text { - } 100 \text { million annual revenue } \\
\text { - Urban environment } \\
\text { - Already received 'Municipality status' }\end{array}$ & $\begin{array}{l}\text { 'Upa-Mahanagarpalika' } \\
\text { (Sub- Metropolitan City) }\end{array}$ \\
\hline & $\begin{array}{l}\text { - Population with } 20000 \text { inTarai and } 10000 \text { in } \\
\text { mountain and hill area. } \\
\text { - } 5 \text { million annual revenue in Tarai and } \\
500000 \text { in hilland mountain. } \\
\text { - Minimum urban facilities. }\end{array}$ & Nagarpalika ( Municipality) \\
\hline $\begin{array}{l}\text { After re- } \\
\text { structuring } \\
\text { the nation ) }\end{array}$ & - Minimum urban facilities. & $\begin{array}{l}\text { Municipal (Local administrative unit). } \\
\text { Minimum requirement hasn't mentioned. } \\
\text { Existing Municipal unit are based on } \\
\text { political decision. }\end{array}$ \\
\hline
\end{tabular}

Source: Chapagain, 2008 
The above table mentions the changing criteria of defining concept and definition of urban center. The criteria in defining urban area has been changed in every census. However, after 1961, population size, annual income and minimum facilities has considered as fundamental basis to declare locations as urban area or municipality. In different times, municipality's boundary has extended by merging adjoining area or it has merged two or more than two rural areas having small market centers and thereby declared a new municipality.

Local self-government act, 1999 categorized the existing urban location into municipality (supmetropolitan and metropolitan city but the criteria of classification were general. At present, there are two types of local administrative unit - Municipality (Nagarpalika) and Rural Municipality (Gaupalika). According to the new administrative structure, district is further divided to Gaupalika and Nagarpalika. Both are to some extent similar character as there are large rural areas and agricultural based population in Nagarpalika as well. However, Nagarpalika still consists of market centers, and is little advanced area (Jnawali, 2004).

\subsection{Trend and Level of Urban Population and Size}

Due to the reclassification and the extension of area together, both urban population and number of urban localities has changed. The proportion of urban population in the country has increased from 2.9 percent in 1952/54 to 42 percent in 2015. Trend and level of urban population is given in Table 2.

Table2. Trends and level of urban number and population

\begin{tabular}{|l|l|l|l|l|l|}
\hline Census year & \multirow{2}{*}{$\begin{array}{c}\text { Number of } \\
\text { urban places }\end{array}$} & Total Urban & \multirow{2}{*}{$\begin{array}{c}\text { Urban } \\
\text { population }\end{array}$} & population (\%) & \multicolumn{2}{|c|}{ Growth rate of population (\%) } \\
\cline { 5 - 6 } & 10 & $2,38,275$ & 2.9 & - & National \\
\hline $1952 / 54$ & 16 & $3,36,222$ & 3.6 & 3.4 & - \\
\hline 1961 & 16 & $4,61,938$ & 4.0 & 3.1 & 1.65 \\
\hline 1971 & 23 & $9,56,721$ & 6.4 & 7.3 & 2.07 \\
\hline 1981 & 33 & $16,95,719$ & 9.2 & 5.7 & 2.66 \\
\hline 1991 & 58 & $32,27,879$ & 13.9 & 6.4 & 2.08 \\
\hline 2001 & 58 & $45,23,820$ & 17.1 & 3.8 & 2.25 \\
\hline 2011 & 130 & 71,01677 & 27.6 & 8.0 & 1.35 \\
\hline 2014 May 8 & 191 & 9403977 & 35.5 & & 1.35 \\
\hline 2014 Dec & 217 & 11041504 & 41.7 & - & - \\
\hline 2015 & & & & \\
\hline
\end{tabular}

Source: CBS, 1095, 2003, 2014.

The percentage of urban population and the number has been continuously changing. During 1952/54 (fifth census), the total urban population was only 2.9 percent under 10 prominent settlement. In 2061, the urban population was 336222(3.6\%) following the growth rate of 3.4 percent which was far higher than annual national average(1.65\%).In 1981 census, the number of urban centers reached to23 following the size of total urban dwellers to 6.4 percent. More interestingly, during this period, urban population growth rate was observed to 7.3 percent which was far higher in the history of Nepalese census. In 1971 and 1991, the growth rate was 3.1 and 5.7 respectively that both rate were low compared to 1981census. This scenario is due to classification, reclassification and changing geographical boundary of urban area and might be the causes of under enumeration of population in 1971 and over enumeration in 1991 census (Chapagain, 2008). Both volume and growth rate of population of urban area measure the level of urbanization (CBS, 2014). During the period of 1991 to 2001 census, the number of urban center were 58 which was declared by adding 25 new urban centers in the previous list as $13.9 \%$ people were as urban dwellers. At that time, the annual average urban population growth rate was 6.4percent. After 2011 census, the number of urban center increased rapidly. In May 2014, government declared 130 municipalities in which 72 newly declared municipalities were also added. The growth rate was also higher (8.0\%) in comparison to average national population growth rate $(1.35 \%)$. In the month of December of same year, government again declared other 61 municipalities. Government kept continue the task of declaring new urban area. Government made 217 municipalities in the year of 2015 by declaring other 26 newmunicipalities. It shows that the concentration of population is increasing to facilitated area. Now 41.7 percent population are as urban dwellers. But growth rate is inacceptable to use as demographic indicator because the increment of urban population each year is by merging rural area (VDCs) but is not the result of natural growth. This indicator is crude and roughly comparable only. After the declaration of the constitution of Nepal in 2015, the government has restructured the country and it has adopted a 
federal system having local, provincial and national level government. It is thereby, the total number of municipalities including Metropolitan and Sub-metropolitan cities has become 293 that consists of about 62 percent of the total population of the country (Chapagain, 2018).

\section{Distribution of Municipalities by Province}

Constitutionally, Nepal is divided into 7provinces. The province is further divided into districts. The urban localities and population size vary by province. The number of urban centers of certain political area represent the level of development and state off farm population of that area. Literally, state of urbanization indicates the employment structure, level of development and standard of living. The distribution of urban areas by province is given in Table 3 .

Table3. Urban centers by province

\begin{tabular}{|l|l|l|l|l|}
\hline \multirow{2}{*}{ Area } & \multicolumn{2}{c|}{ Number of Urban } & \multirow{2}{*}{ Total } \\
\cline { 2 - 4 } & \multicolumn{1}{|c|}{ Municipality } & Sub-metropolitan & Metropolitan & \\
\hline Province 1 & 39 & 2 & 1 & 42 \\
\hline Province 2 & 32 & 3 & 1 & 36 \\
\hline Province 3 & 41 & 1 & 3 & 45 \\
\hline Province 4 & 23 & - & 1 & 24 \\
\hline Province 5 & 29 & 4 & 0 & 33 \\
\hline Karnali Province & 12 & 0 & 0 & 12 \\
\hline Province 7 & 24 & 1 & 0 & 25 \\
\hline Total & 200 & 11 & 6 & 217 \\
\hline
\end{tabular}

Source: CBS, 2014,Chapagain, 2018.

It is seem that province no. 3 has higher urbanization where 45 urban center including three metropolitan cities namely Kathmandu, Baratatpur and Lalitpur and one sub-metropolitan cityHetauda, are located. Similarly, province 1 is in second position where 42 urban centers including one metropolitan city, Biratnagar, are located. Karnali province is the least urbanized where only 12 urban center are located.

\subsection{Size Class and Hierarchy of Urban Area}

The existing municipalities vary in terms of population size. The population size of the municipality ranges from 20,000 to 100,000 and above. The big cities are 13 in 2015 and the small cities by population is 34. Lowest population size are found in the municipality of Mountain and Hill region. Size class and number of urban centers is given in Table 4.

Table4. Size class distribution of municipalities (1952/054- 2015 AD)

\begin{tabular}{|l|l|l|l|l|l|l|l|l|l|}
\hline \multirow{2}{*}{ Size Class } & \multicolumn{10}{|c|}{ Years( AD) } \\
\cline { 2 - 11 } & $\mathbf{1 9 5 2 / 5 4}$ & $\mathbf{1 9 6 1}$ & $\mathbf{1 9 7 1}$ & $\mathbf{1 9 8 1}$ & $\mathbf{1 9 9 1}$ & $\mathbf{2 0 0 1}$ & $\mathbf{2 0 1 1}$ & $\mathbf{2 0 1 5}$ & Rank order \\
\hline Below 20000 & 7 & 12 & 9 & 7 & 8 & 8 & 6 & 34 & Second \\
\hline $20000-49999$ & 2 & 3 & 5 & 13 & 14 & 34 & 25 & 134 & First \\
\hline $50000-99999$ & 0 & 0 & 1 & 2 & 8 & 11 & 16 & 16 & Third \\
\hline 100000 and above & 1 & 1 & 1 & 1 & 3 & 5 & 11 & 15 & Forth \\
\hline Total & 10 & 16 & 16 & 23 & 33 & 58 & 58 & 217 & \\
\hline
\end{tabular}

Source: CBS, 1995,2001,2011;MoFALD,2015

The above table (table 4) mentions the size class of municipal population. The average population size of municipality is 55381. The annual population growth rate is about $8.02 \%$. Out of 217 urban center, 172 have less than average urban population size. More respectively, municipalities falls under population size of 20000-49999 is quite higher which account for 134. Large cities are gradually increasing which has increased from 1 in 1952/54 to 15 in 2015.

\subsection{Distribution of Urban Center by Ecological Region}

There is uneven distribution of municipalities by ecological region. The Mountain region has a few urban centers due to low population size, scatter settlement and vertical migration trend from Mountain to Hill and Tarai. Secondly, the major criteria of population and annual income is inadequate for being the municipality in Mountain and Hilly regions. Nearly half of the total municipalities are located in Tarai region (Table 5) 
Table5. Distribution of municipalities by ecological region

\begin{tabular}{|l|l|l|l|l|l|l|l|l|}
\hline \multirow{2}{*}{$\begin{array}{c}\text { Ecological } \\
\text { zone }\end{array}$} & \multicolumn{7}{|c|}{ Municipality by census year } \\
\cline { 2 - 10 } & $\mathbf{1 9 5 2 / 5 4}$ & $\mathbf{1 9 6 1}$ & $\mathbf{1 9 7 1}$ & $\mathbf{1 9 8 1}$ & $\mathbf{1 9 9 1}$ & $\mathbf{2 0 0 1}$ & $\mathbf{2 0 1 1}$ & $\mathbf{2 0 1 5}$ \\
\hline Mountain & - & - & - & - & - & 2 & 2 & 15 \\
\hline Hill & 5 & 8 & 7 & 9 & 13 & 27 & 27 & 95 \\
\hline Tarai & 5 & 8 & 9 & 14 & 20 & 29 & 29 & 109 \\
\hline Total & 10 & 16 & 16 & 23 & 33 & 58 & 58 & 217 \\
\hline
\end{tabular}

Source: CBS, 1995, 2001, 2011; MoFALD 2015

The above table acknowledges that the there was no municipality in mountain region before 2001 census. In 1997, Khandabari of Sunkhuwasabha district and Bhimeshwar of Dolakha district from Mountain region were they only two municipalities but there has been 15 municipal area from Mountain region at present. The number of municipality in Hill region has been gradually increasing. The number of municipalities from Hill region has increased from 5 in 1952/54 to 27 in 2001 and 95 in 2015. While in the case of Tarai, the total number of municipalities were only5 in 1952754 that reached to 29 in 2001 and 109 in 2015.

\subsection{Municipal Unit by State and District}

Nepal is recognized constitutionally the federal state. Politically Nepal is divided into 7 province, 77 districts and 753 local units.753 local units are further categorized into Nagarpalika and Gaupalika. The previous Village Development Committees (VDCS) and Municipalities have been rearranged as Municipality and Rural Municipality by merging the previous local units. Out of 753 local units, 293 are Nagarpalika and 460 Gaupalika. Nagarpalika is further categorized into Nagarpalika, Upamanhanagarpalika and Maha Nagarpalika. The distribution of the Nagarpalika by province is given in Table 6.

Table6. Situation of Nagarpalika by province

\begin{tabular}{|l|l|l|l|l|l|}
\hline \multirow{2}{*}{$\begin{array}{c}\text { Name of } \\
\text { province }\end{array}$} & \multirow{2}{*}{$\begin{array}{c}\text { Number of } \\
\text { district }\end{array}$} & \multicolumn{2}{|c|}{ Number of Nagarpalika unit by types (Administrative Units) } & $\begin{array}{c}\text { Total } \\
\text { population }\end{array}$ \\
\cline { 3 - 6 } & 14 & 1 & 2 & 46 & 58.5 \\
\hline province 1 & Maha-naparkalika & Upa- Mahanagrpalika & Nagarpalika & 71.9 \\
\hline province 2 & 8 & 1 & 3 & 73 & 71.5 \\
\hline province 3 & 13 & 3 & 1 & 41 & 60.1 \\
\hline province 4 & 11 & 1 & 0 & 26 & 51.7 \\
\hline province 5 & 12 & 0 & 4 & 32 & 49.3 \\
\hline Karnali Province & 10 & 0 & 0 & 25 & 58.9 \\
\hline Province 7 & 9 & 0 & 1 & 33 & 100 \\
\hline Total & 77 & 6 & 11 & 293 & \\
\hline
\end{tabular}

Source: CBS, 2014; Chapagain \& Ghimire, 2018.

Constitutionally Nepal is the federal Democratic Republic. It follows the federal system so country is divided into province and districts. The district is further divided into several local administrative units i.e. gaupalika and nagarpalika. Further divided to municipality, sub-metropolitan and Metropolitan. In terms of province, province two has highest (49\%) population living in Nagarpalika. It is followed by province $3(71.5 \%)$. The lowest percentage $(51.7 \%)$ of urbanization is in province 6.

\section{CONCLUSION}

The level of urbanization has been rapidly increasing in Nepal. This rapid urban growth is mainly contributed by migration from rural areas to urban areas and mainly due to the changes in administrative boundary so that the minimum number of population criteria has met to declare the area as municipal area. Although, population, annual income, and level of infrastructure development are set as the basic criteria to declare municipality, the political decision and the population criteria has been adopted in practice. Thus urbanization has increased from 2.9 in 2052/54 to 14 percent in 2001, 2 percent in 2015 and 62 percent in 2016. The urbanization does not have temporal variability it has also spatial variability in terms of distribution. The Mountain region has least (15 out of 217) urban centers where as Tarai has the highest number (109 out of 217)of urban centers. Similarly by province, province no 3 , province no 1 and province no 2 have higher number of urban centers compared to other provinces. 


\section{REFERENCES}

[1] Subedi, B. P.(2014). Urbanization in Nepal: Spatial pattern, social demography and development. In Population Monograph of Nepal, Vol lll(pp.95-149). Kathmandu: Central Bureau of Statistics.

[2] Chapagain, P.S\& Ghimire P.K. (2018). Ekta school atlas.Kathmandu: Ekta Books.

[3] Chapagian,P.S. (2008).Special aspects of population, migration and urbanization in Nepal. Kathmandu: Paluwa Prakashan.

[4] Chapagain, P.S. (2018). Special aspects of population, migration and urbanization in Nepal (2nd Ed.). Kathmandu: Highland Publishers.

[5] Sharma, P.(2003). Urbanization and development. In Population Monograph of Nepal,Vol ll (pp.375-412). Kathmandu: Central Bureau of Statistics.

[6] Jnawali,D. (2004). Rural-urban interaction a geographical perspective. Kathmandu: students' Books Publisher and Distributors.

[7] CBS. (2014). Population Monograph of Nepal. Kathmandu: Central Bureau of Statistics.

[8] CBS, (2003). Population Monograph of Nepal. Kathmandu: Central Bureau of Statistics.

\section{AUTHORS' BIOGRAPHY}

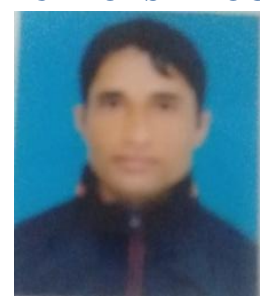

Damodar Chapagain is the Teaching Assistant working in Mahendra Ratna Multiple Campus, Tribhuvan University, Ilam since 2004. He has been teaching population studies to undergraduate students. His areas of research are population dynamics of Nepal with special focus to population situation, urbanization and migration. He has published more than fifteen research articles and four books. He has completed a few research supported by various organizations such as university, local government and non-government organizations. He has also presented papers in various international and internal conferences.

Citation: Damodar Chapagain. "Present Situation of Urbanization in Nepal". International Journal of Humanities Social Sciences and Education (IJHSSE), vol 5, no.12, 2018, pp. 170-175. doi:http:// dx.doi.org/10.20431/2349-0381.0512001.

Copyright: (c) 2018 Authors. This is an open-access article distributed under the terms of the Creative Commons Attribution License, which permits unrestricted use, distribution, and reproduction in any medium, provided the original author and source are credited. 